\title{
An answer from Marxist economics to Weber's hypothesis about China: a concurrent discussion of the direction of rural reform in China
}

\author{
Jiguo Yang \\ School of Economics, Xiamen University, Xiamen, China
}

\begin{abstract}
Purpose - Weber's hypothesis about China is the hypothesis forwarded by Weber that why capitalist production did not appear in eastern countries such as China in the first place. Weber considered that the reason may be Chinese Confucianism and Taoism lack protestant ethic like Western countries.

Design/methodology/approach - The clarification has aroused wide discussion, meanwhile, East Asian capitalism belonging to the Chinese cultural circle has successfully refuted Weber's proposition. Chinese scholars have a broad debate around this topic while no agreement has been reached. This paper tries to explain Weber's hypothesis by Marx's theory of capital origin, which can be explained that the landlord economy caused by China's federal society under centralism leads to the result that the commodity of labor cannot exist in that environment.

Findings - The answer from Marxist economics has not only solved an enormous theoretical problem, but also it has vital practical significance. It easily clarifies the fact that the commodity of labor in full sense still cannot emerge in China nowadays, which is an important reason causing China to enter the New Normal and New Era. Originality/value - Therefore, it leaves China the only way of the socialist road with Chinese characteristics and revitalizing China's rural economy, which means China can only promote rural industrialization and urbanization under the principle of adhering to rural collective ownership, while implementing various forms of integrated agricultural and industrial business models based on local conditions.
\end{abstract}

Keywords Weber's hypothesis about China, An answer from Marxist economics, Commodity of work force, The direction of rural reform, Collective ownership

Paper type Research paper

\section{Introduction}

Weber's hypothesis about China is one of the two questions from Weber's hypothesis, which are: (1) why was capitalist production first established in Western countries? (2) why capitalist production did not appear in eastern countries such as China in the first place? German socialist Weber (Max Weber, 1864-1920) answered the first question in his book The Protestant Ethic and the Spirit of Capitalism that protestant ethics accelerated the birth of capitalist spirit, thereby promoted the development of capitalism in Western countries. Weber gave an answer to the second question in another book Religionen in China: Konfuzianismus and Taoismus that the reason why capitalist production did not appear in China at the earliest maybe Chinese Confucianism and Taoism lack protestant ethics as

(C) Journal of Xiamen University (Arts and Social Sciences). Published in China Political Economy. Published by Emerald Publishing Limited. This article is published under the Creative Commons Attribution (CCBY 4.0) licence. Anyone may reproduce, distribute, translate and create derivative works of this article (for both commercial and non-commercial purposes), subject to full attribution to the original publication and authors. The full terms of this licence may be seen at http://creativecommons. org/licences/by/4.0/legalcode

Originally published in Simplified Chinese in Journal of Xiamen University (Arts and Social Sciences).
Direction of rural reform in China 
CPE 3,1

Western countries do (Guo, 2015). The reason for raising this question is that before the establishment of Western capitalist production, in a feudal society that lasted thousands of years, China's population, economic development, transportation system, urbanization and business economy, as well as the market maturity, profit-seeking consciousness and scientific and technological development are far superior to those of the West. Besides, the seeds of capitalism appeared at an early time of Tang and Song dynasty compared to the West, especially in Ming and Qing dynasty, the industry and commerce of regions south of Yangtze River were quite developed, for example, a large number of freelance labor patterns, such as "machine owner's contribution and machine worker's contribution" and "no master-servant status", have appeared (Zhou, 2010). According to that, capitalist production should appear in China firstly as a superior mode of production than the feudal one. However, the answer given by history is that this "advanced" mode of production built up in Western Europe at the earliest, meanwhile, China has become an attractive piece of meat to the Western capitalist division and has become a Western semicolonial. With such historical facts, not only the Chinese are wondering why, but foreigners are also very interested in it. Weber believes that the answer cannot be found from social conditions such as material and political systems, and the answer must be spiritual, that is, cultural. In other words, capitalist society cannot be conceived in traditional Chinese culture.

Weber's hypothesis about China has attracted related research in China, and a group of scholars discussed why China has not been in the lead when it comes to establishing capitalist production from the perspectives of sociology, culture and religion. It is sure that this issue has caused great controversy, and the criticism of Weber's proposition has not stopped. Japan, which belongs to the "Confucian heritage cultural" same as China, and the success of the capitalist development of "Four Little Dragons", seem to have "falsified" the "Weber proposition." The research on the Chinese hypothesis aims to solve a fundamental theoretical puzzle, as well as having a significant practical meaning. It involves the problem of how to construct under the socialist road with Chinese characteristics, especially the direction of rural reform, which directly affects China's future and whether the "the Chinese dream" can be realized. But so far there is no consensus on the answer to the "Weber's hypothesis about China," this paper attempts to analyze and solve this problem by Marxist economics theory.

\section{Answers to "Weber's hypothesis about China" from Chinese academia}

This paper is not intended to discuss whether the answer Weber holds toward Weber's hypothesis about China is right or wrong. The reason is that first, Weber's hypothesis itself has drawn broad controversy and second, the answer has been "falsified" by practice. China's domestic academic field has given all kinds of answers to the question that why capitalist production did not appear in China in the first place, the number of which is large, while all opinions can be divided into two categories: "multi-factor" theory and "single-factor" theory.

\section{1 "integrated-factor" theory or "multi-factor" theory}

According to the number of influencing factors, the theory can be further divided into "twofactor" theory, "three-factor" theory, "four-factor" theory and so on, which are quite similar with difference in the quantity of influencing factors. Therefore, this paper takes the "threefactor" theory, a typical one, as an example, the opinion of which is the long feudal autocracy, the traditional values of Confucian culture and the relatively closed geographic environment are three linked factors that hinder the development of capitalist production in China. The feudal autocracy state system has four features: (1) pursuing for a long period of stability and maintaining the traditional agrarian society; (2) ruling the country by etiquette and ruling pluralism with one element; (3) to maintain the unification, the "face problem" is derived; 
(4) these aspects lead to the difficulty of producing innovative talents. The values of Confucian culture have "unified" the whole China. The characteristics of Confucian values are that they value personal loyalty over profit, emotion over the law and rhetorics over truth seeking, which caters to the needs of the autocratic feudal empire. A vast territory, abundant resources and the relatively closed geographic environment have the following characteristics: (1) closure effect. Due to the less external demand and lack of economic incentives for outward expansion, the development of international trade is hindered; (2) conservative effect. Due to insufficient communication with the outside world and the lack of competitors for a long time, as a result, there is a lack of awareness of competition and crisis, and the lack of motivation for technological innovation is evitable. The aforementioned four aspects are entangled with each other. Cause becomes effect and effect become the cause, which leads to the country's adherence to the old and the inertia of learning from the old and rejecting the new, which hinders China's technological innovation and economic development, as well as the formation of capitalist production in China.(Xia and Zhan, 2002)

\section{2 "Single-factor" theory}

There are many viewpoints, such as: "the theory of backward productivity," "the theory of strong national economy," "the theory of system," "the theory of difference in social structure," "the theory of non-independence of merchant capital" and "the theory of interruption due to foreign aggression" and so on. The single-factor theory does not exclude other factors' function but believes one factor plays a major or decisive role, which seems more appropriate to be called "the main factor theory."

2.2.1 "The theory of backward productivity". The theory considers that though the seeds of capitalism appeared in an early time compared with the West, it has not changed much in hundreds of years because productive forces in China at that time were lagging behind and the level of productive forces was not sufficient to breed capitalist production. According to the basic principles of Marx's historical materialism, this theory holds the opinion that productivity at a necessary level is the decisive condition for the occurrence of capitalist production. In the modern history, China has acted as an unconscious tool of history and promoted the emergence of capitalism because of the invasion of foreign capital, the introduction of advanced productive forces, that is, the role the activities of foreign capital has played in spreading advanced technology and demonstration. Although the invasion of foreign capital hinders the development of Chinese capitalism on the one hand, while on the other, it promotes the emergence of capitalism, which is a contradictory phenomenon of the unity of opposites. (Zhu, 2001)

2.2.2 "The theory of strong national economy". During the feudal period, the private sector in China including private industries and business, landlord economy and peasant economy were relatively weak, while the feudal economy was extremely strong. Under the long-term control and influence of feudal economy, the development of agricultural productivity in China was rather slow compared to the population increase in Ming and Qing dynasties. Under the circumstance of low productivity level, the separation of agriculture and handicraft, the internal labor division of agricultural production and the commercialization of agricultural products were only developed in some regions south of the Yangtze River, while the general level around the country was still very low. The inadequate development of the private economy in most parts of the country has not only greatly restrained the development of the seeds of capitalism in China, but also affects the modernization of the Chinese economy. (Liu, 1995)

2.2.3 "The theory of system" (centralism). Chinese feudal system is centralism, the characteristics of which include first, the natural economy that combines small-scale peasant economy and household handicraft; second, the trinity of land, commercial capital and usury;
Direction of rural reform in China 
CPE 3,1

third, the strict control of household registration by the autocratic government; fourth, the tradition of emphasizing on agriculture while binding commerce in every dynasty; fifth, the restraint of the Bao-Jia system (an administrative system organized on basis of households) and the clannism on the public and the fetter of the patriarchal ideology on the mind-set and so on. These features made it hard for the commodity economy and citizen stratum to be fully developed. As a result, when capitalism in Western Europe entered the stage of primitive accumulation of capital from its beginning stage, established capitalist system and carried out the industrial revolution, China still staggered in the status of precapitalism. (Feng, 1990)

2.2.4 "The theory of non-independence of merchant capital". The representative one is from The Original Theory about China's Economy written by Professor Wang Yanan, a famous Marxist economist, who is one of the writers of the first cover-to-cover translation of Das Kapital. The theory believes that the commercial capital and interest-bearing capital of China's precapitalism are different from those of Western European precapitalism: the latter is based on the feudal lord economy while the former is based on the landlord economy. The land of the feudal economy cannot be traded freely while the land of the landlord economy can be traded freely. In this way, Chinese businessmen will purchase a lot of lands once they have money, so that the landlord and the businessmen are the same ones, which means the commercial capital cannot be operated independently and cannot be converted into industrial capital. (Wang, 2000: p. 116) One of the most prominent characteristics of Chinese commerce capital is that in the negative sense, it requires a certain degree of backwardness in society. In the positive sense, it needs advanced society and the development of productive forces to produce surplus products to be exchanged. However, these advanced features should not reach the limit that capitalism replaced feudalism, which means feudalism will lose its grip on domination. (Wang, 2000: p. 116) The urban economy of China's precapitalist production has no independence, the same as the rural economy. The structure is that cities rule the countryside at the political level while depending on them economically, and it fails to develop an urban economic center that is independent of the countryside. (Feng, 1990) This view is essentially the same as that of Professor Wang Yanan. As interest-bearing capital and merchant capital are broadly defined as commercial capital, if commercial and agriculture are regarded as two economic forms, then the urban economy and rural economy are corresponding to them.

2.2.5 "The theory of interruption due to foreign aggression". This theory holds that although China had all required conditions for the emergence of capitalism, the imperialist invasion interrupted the historical process of capitalism's sprout and emergence, which made China to become a semifeudal and semicolonial society. (Liu and Zhang, 2013)

2.2.6 "Geographic environment impact theory". The geographic environment has an influence on the level of productivity, and the level of productivity affects production relations. However, the theory of geographic environment impact is not equal to the theory of environmental determinism. At the early stage of human society, the geographic environment has a greater impact, and since then human initiative has become more and more important. To the development of capitalism, the origin of capitalism does not often occur in regions with conducive geographic conditions rather than those with poor conditions. Because of the relatively good geographic environment, the origin of capitalism did not occur in China. (Zhang and Ma, 1987)

2.3 A brief comment on the opinions discussed earlier. Though the "single-factor" theory and "multi-factor" theory are not the same in many ways, they are consistent to some extent. Although there is usually more than one factor that will affect or determine the result of one thing, these factors have primary and secondary positions instead of paralleling together, or they all derive from one specific factor, which accords with the fundamental principle of materialistic dialectics. Those opinions discussed earlier all expound the reason why China "can firstly" or "cannot" enter into capitalist society more or less. The defect of "multi-factor" 
theory is that it has not divided all factors into primary and secondary keys, instead, regarded them as the answer to "Weber's hypothesis about China," while no decisive aspect has been found. "Single-factor" theory mostly concerns multiple factors that derived from one and jointly take effect, which is better in methodology aspect. However, there are numerous different opinions among the "single-factor" theories, which illustrates that the true answer of "Weber's hypothesis about China" has not been found or has not been intensively studied. Among "single-factor" theories, though the exposition of "the theory of system" (centralism) and "the theory of non-independence of merchant capital" are not the same, they both regard the "landlord economy" under centralism as the decisive factor. The paper believes that this point of view is most likely to be the right answer. However, this view still fails to penetrate the essence of the problem and does not seek the key condition that the "landlord economy" in the feudal centralized system cannot meet the needs in the process of commercial capital transforming into industrial capital, that is, the transformation of currency into the capital in Marx's Das Kapital.

\section{An answer from Marxist economics to Weber's hypothesis about China}

Das Kapital, a great work of Marx, is an economic classic of Marx studying the emergence, development and operation of capitalism. In the book, Marx incisively clarifies the origin of capitalism by the method of historical materialism. At present, various research on "Weber's Hypothesis about China" discussed from the aspects of politics, culture, religion, social system and environment and so on. There are many different opinions and some of them are even opposite to each other. Few studies are based on the theory of the origin of capitalism in Marx's Das Kapital. This paper tries to use it to analyze. As long as we analyze whether China has the condition that the emergence of capitalism needs, we can answer "Weber's hypothesis about China" theoretically.

\subsection{The theory of "the origin of capitalism" in Das Kapital}

The mode of production of the capitalist is based on capital and aimed at surplus value. Capital, as the logical starting point of capitalism, is the fundamental force of it. All the rules and regulations of capitalism are governed by capital. Capital is the light of all. Therefore, to study the origin of capitalism should start with studies of the origin of capital, in another word, the origin of capital is the origin of capitalism. There are certain historical and economic conditions for the origin of capital.

3.1.1 The historical condition of the origin of capital (capitalism). Capital, as the product of history, is an evitable outcome at a certain development level of currency. The fundamental condition of currency turning into capital is work force transforming to commodity, which needs two necessary prerequisites: first, the workforce must be freeman who has the ownership of his own labor so that he can have the right to sell his labor power and make money. If that is not the case, the workforce, as a serf in feudal relations, has no right of selling his labor power. Second, apart from labor, the workforce has no other thing to sell, that is to say, he has lost his means of production. If that is not the case, even if the workforce is freeman, he may not be willing to sell his labor power if he can make a living by his means of production.

3.1.2 The economic condition of the origin of capital. When historical condition meets the requirement of the emergence of capital, there is no guarantee that all currency can be transformed into capital. Marx said that not every amount of money or value can be converted into capital. On the contrary, the premise of this transformation is that a single currency holder or commodity holder has a certain minimum amount of currency or exchange value. This is not only because the purchase of labor and means of production needs a certain amount of currency, but also the principle of capitalism is to produce for surplus value. The capitalist will not purchase if the outcome can only cover the cost with no surplus value
Direction of rural reform in China 
CPE 3,1

though the monetary aggregate can cover a certain quantity of means of production to make products; reproduction could not be conducted if there is some surplus value that only meets the need of capitalist's own assumption without source of capital accumulation. Therefore, one of the economic conditions for currency being converted into capital is that the monetary aggregate for purchasing labor and means of production is large enough to produce surplus value, meanwhile, the surplus value still has enough "balance" after meeting the consumption of capitalists and the simple reproduction.

It needs a minimum scale for currency to transform into capital. The "qualitative change" of the capital guarantees the process of currency being converted into capital from the aspect of historical condition, and the "quantitative change" of it meets the need of the economic condition. The early history of capitalism contains a stage of "primitive accumulation" of capital, meeting the requirement of "quantitative change," which is the "historical" demonstration of the economic conditions of currency being converted into capital. Since there was no surplus value in the society before the emergence of capital, and surplus value is the source of capital, the "meta-capital" before the emergence of surplus value, the first capital can only reach the "minimum amount" through violence.

3.1.3 The generation process of capital (capitalism). The premise of capital formation is the labor turning into a commodity. The trade of commodity of labor power, the same as selling other goods, should follow the principle of equivalent exchange. At this point, contradiction will be generated in the equation of capital circulation: $G-\mathrm{W}-\mathrm{G}+\Delta \mathrm{G}$ with $W$ containing means of production and workforce, $\Delta G$ being the appreciation of the invested capital, that is, surplus value. Since the equation should be under the principle of equivalent exchange, why is there an extra $\Delta G$ ? Specifically, (1) the contradiction of equivalent exchange and the appreciation of original value; (2) capital and surplus value cannot be generated by equivalent exchange in the field of goods exchanging, while they cannot be apart from the circulation process. Marx said that capital cannot emerge in the process of circulation, but it cannot be produced without circulation.

Concerning the first contradiction, the appreciation $\Delta G$ cannot be produced in circulation because the purchase of workforce and means of production is all under the principle of equivalent exchange. Currency cannot be converted into the capital in circulation since $\Delta G$ does not generate in circulation. Though the principle of circulation means the exchange of equal values, as for workforce and means of production, the purchase is different with that of consumer goods. The purchase of workforce and means of production is for appreciation while the latter is for direct consumption. The use value of the former is the method of appreciation, which embodies the "social attributes" of commodities; the use value of the latter is the satisfaction of needs of people, which originates from the "natural attributes" of commodities. The secret of appreciation is the application of the "social attributes" by using labor and means of production to make production. If laborers are not employed, there will be no appreciation even though the means of production are purchased.

For the second contradiction, circulation, even goods were bought cheap and sold dear, which is a zero-sum game, no surplus value can be produced in this process. If a special commodity - labor cannot be exchanged at equal values in circulation, there is no possibility of producing surplus value. The reason is that labor, as a special commodity, can produce more value than itself. Capitalists use labor for production, that is, a way of creating values. Besides creating their own values, laborers can supply surplus workforce and create surplus vales. This is the answer to solve the contradiction of the general formula for capital.

\subsection{An answer from Das Kapital to Weber's hypothesis about China}

The origin of the capitalism in Das Kapital shows that the birth of capital is the logical starting point of capitalism, and the birth of capital requires two conditions: first, labor being 
converted into a commodity, and the emergence of the wage-labor system or the formation of the labor market; second, the volume of money that is yet to be "hatched" into capital should reach a certain number, that is to say, the "commercial capital" in precapitalism should be accumulated to a certain amount to be "hatched" into "industrial capital." The first condition is the decisive and major one. If labor market has not been formed, even with enough amount of the "commercial capital" in precapitalism, "industrial capital" still cannot be converted, which means the capitalist mode of production cannot be "hatched." Once the first condition is satisfied, even the amount of the "commercial capital" cannot meet the quantity of "industrial capital," the number will be reached sooner or later, and the birth of capitalism is only a matter of time instead of feasibility. The following part will study these conditions and consider whether they could have been satisfied in the background of feudal society in China.

3.2.1 How could Western Europe satisfy the two conditions mentioned earlier to realize the origin of capitalism? To contrast, the analysis of the conditions of origin of capitalism in Western Europe is firstly discussed, where first capitalism emerged. According to the order of history, the issue of "money aggregate" was the first to be solved, which means to accumulate a large amount of commercial capital in the precapitalism period. The capital is not the capital in true meaning since it cannot produce surplus value and the "commercial profit" is simply the result of buying cheap and selling dear. The true commercial capital should be subject to industrial capital and be used for circulation after the real capital emerged. To reach the required amount of money to "hatch" the capital, merchant capitalists cooperated with the feudal monarch by lending to them sufficient amount of money to "centralize the power." In this way, the feudal landlord system with scattered "disintegration" situation was converted into the feudal system with "centralism." The monarch could expand the army for expansion with the financial support of merchants and as the give-and-take condition, while merchants could gain franchising and monopolistic commercial profit. Besides, they could enact new laws and make economic policy on "mercantilism" by the help of the national army and administrative power. Under the intensive intervention of the power owner, commercial trade expanded rapidly throughout the world and colonial markets were violently opened up, completing the "primitive accumulation of capital." The sufficient accumulation of commercial capital is not equal to the successful emergence of the capitalist system. The process of "primitive capital" (commercial capital) being transformed into industrial capital is still needed, which is to establish enterprises and produce aiming at making a profit. Though merchants and the feudal monarch were "cooperated" under the condition that each takes what he needs at the "primitive accumulation of capital" period, the premise of this "cooperation" is that the boundary of "commercial" cannot be broken and the field of industry cannot be touched. Owing to the difference in class of merchants and the feudal monarch, their fundamental interests are widely divergent. Laborers, same as "serf" of the feudal landlord, have no freedom and cannot sell their labor power to others except the landlord (there is no sale of labor power in feudal manors since the labor power belongs to the landlord instead of the labor himself), so labor commodity that industrial capital needs cannot be purchased. To make a labor commodity possible, a newly developed merchant capitalist class can only overthrow the rule of the feudal system to destroy the serf system and free the serf. With the slogan of "human rights" and "freedom," the newly developed merchant capitalist class led serfs to carry out the bourgeois revolution and overthrew the feudal system, and labor gained freedom. However, the freed serfs had no means of production, to make a living, they had to sell their labor power to the capitalist. In this way, the commercial capital in the precapitalism was converted into industrial capital successfully and the capitalist mode of production has been established.

3.2.2 Has China satisfied the two conditions for the emergence of capitalism?. The paper will continue with the analysis of the condition of the "quantity of money." In terms of the quantity of money, in fact, the condition of China is better than that of Western Europe at that
Direction of rural reform in China 
CPE

3,1

168

time: first, the seed of capitalism appeared earlier, not only a certain amount of commercial capital was accumulated, but also the capitalist mode of production emerged in some areas. That is to say, commercial capital had already converted into industrial capital. At that time, long-distance trade of domestic bulk commodities had some development, the national market was preliminarily formed and the overseas international trade had developed to a certain scale. The development of commercial capital in China has accelerated the urbanization as well as the historic change of merchants' social status. Even if with insufficient "quantity of money" to produce capital, why could not China go on "primitive accumulation of capital" as Western Europe (Tang, 2005)? Therefore, this condition was not a problem. As for the condition of labor transforming into a commodity, since there are more than 2,000 years of the feudal system of centralism system, which is still up to around 1,500 years counting to the 14th or 15th century when the seeds of capitalism emerged. Unlike Western Europe, the centralism in China was turning the feudal society under "system of enfeoffment" into the feudal society with the "landlord system" instead of coestablished with merchant capitalist class. Under the feudal economy of the landlord system, workers were not only "freeman," but also could own means of production to be small product producers as well. Even when meeting the situation of land annexation, parts of farmers lose their land, who could still rent a piece of land and keep their status as a farmer. Besides, without the land, farmers still owned other means of production, such as farm implements and farm cattle and so on. Owing to the sharpened social conflicts caused by the policy of land annexation, dynasties in China changed over and over again. At the beginning of each new dynasty, the land was redistributed so that farmers without land could get the land again. So, unlike the freed serf, laborers in China were not "have nothing at all." There are two conditions for the workforce turning into a commodity: the freedom of laborers and the "have nothing at all" situation of laborers. Since farmers in China only satisfied the first condition, "capitalists" had trouble purchasing "long-term" labor. The capitalist mode of production cannot be widely found in China and can only stay in the bud.

3.2.3 The productivity matter of the origin of capitalism. According to the basic principle of historical materialism, workforce determines the means of production and economic base decides the superstructure. Based on the theory, some scholars try to find the reason why China had trouble entering into capitalism from the productivity aspect. Therefore, there was "the theory of backward productivity" and "the theory of backward scientific and technological level" in the literature review. The truth is the integrated productivity of China was far above Western Europe at that time. And "the theory of backward scientific and technological level" is to compare the scientific and technological achievements of Western Europe, which were gained through the "industrial revolution" after the establishment of the capitalist mode of production with that of China. The early stage of the establishment of the capitalist mode of production was simply about the centralized division of work and cooperation. And the productivity level of the handicraft factory in Western Europe could never be higher than that of China. Now that productivity decides relations of production, why did the capitalist mode of production appear in Western Europe instead of China with a respectively higher level of productivity? The matter of productivity should be considered on the whole of history and structure of the world instead of individual country. It is the result of the development of productivity that a superior social formation replaces the lower one and human civilization grows from a lower level to higher, which are all driven from productivity. But it does not mean that each country, each region should follow the successive pattern of growing from a lower level of social formation to a senior one. In another word, the country that enters a higher level of social formation must be the country with the highest level of productivity. As long as the productivity of the world as a whole reaches a certain level, a new social form will be bred in the matrix. However, the matrix refers to the whole world rather than a specific country. As for the location of the "matrix," it will be decided by the 
development of the specific historical condition and social contradictions. It may appear in any country regardless of its development level. The hypothesis has been proved to be the truth.

The reason that capitalist mode of production emerged firstly in Western Europe instead of China, which had a respectively higher level of productivity, is that the productivity of the world as a whole reached the level of promoting the emergence of capitalism. In fact, the advanced productivity of China was an important driving force to the birth of capitalism in Western Europe, especially Chinese classical technological products such as gunpowder, papermaking technology, compass and so on. Outstanding thinkers in the world, such as Marx in Germany, Needham in England and Yuka Asahi in Japan, have repeatedly discussed the critical contributions that three major inventions have made in destroying European feudal systems. "The three major inventions" of China, which represents the "advanced productivity" at that time, affected the emergence of Western capitalism. The advanced cultural and political system of ancient China also influenced the Enlightenment Movement $(\mathrm{Yu}, 1991)$. At this point, the advanced productivity of China was regarded as a vital part of the development of productivity in the whole world rather than China itself, because the process of the capitalist mode of production replacing feudalism driven by productivity is the social formation of the whole world rather than some countries or regions. The argument has been testified by the globalization of capitalism.

\section{Inspiration of the answer from Marxist economics to "Weber's hypothesis about China" toward the direction of rural reform in China}

Since "centralism" in China was established far too early, the system of landlord economy under centralism was extremely stable. Under the system, labors could not be transformed into commodity. Marxist theory on solving "Weber's Hypothesis about China" has not only solved an enormous theoretical problem, but also it has important practical significance. The "answer from Marxist Economics to Weber's Hypothesis about China" shows that the situation in China did not satisfy the condition of producing capitalist mode of production in the embryonic period of capitalism. Under the invasion of foreign capital, from the Opium War to the Eighth-Power Allied Forces and then to the Anti-Japanese war, the capitalist path was still not brought out as other colonies did. Thus, after decades of experience of the socialist market economy, can China satisfy the conditions for the birth of capitalism?

\section{1 "The peasant laborer" without the nature of labor power as a commodity in the full sense} After the reform and opening-up, China has carried out the socialist market economy system with Chinese characteristics, mainly containing the public ownership as the main body, along with multiple ownership as well as private economy including foreign investment, which has all witnessed a vigorous development. Under the background of the socialist market economy system, enterprises have become the main body of running a business independently and "hire" the needed workforce from the market. The main part of these employers is mostly surplus labor left from the countryside. From the perspective of form, they posse the nature of labor as a commodity. However, even in private enterprises or foreign-owned enterprises, the "hired" labors from the market are quite different from labor as a commodity in capitalist countries. The distinction is that these "labors as a commodity" in China are not the proletariat that "have nothing at all." They possess contracting land owned by collectives and other means of production in rural areas. They are not "workers" in their original meaning, though being called "the peasant laborer," who are essentially still farmers. Because of the "comparative advantage," the industrial system with "labor-intensive" industries as the main body has been formed at the preliminary stage of the reform and opening-up, based on which
Direction of rural reform in China 
CPE

3,1

the chain of the international division of labor has been added and the socialist market economy has embarked on its journey.

At the preliminary stage of the reform and opening-up, the urbanization level was rather low with over $80 \%$ laborers as farmers. With the development of the market, the needs for labors from the urban economy have been increasingly raised. Owing to the nature of the "dual economy" of the city and countryside, there is a huge difference between rural and urban economy, which means laborers working in cities can earn more money than in rural areas. Thus, more and more farmers chose to leave the land and work in cities, becoming "the peasant labor." The rapid development of the city's industry and commerce required a growing number of "peasant labors," but the number of them still exceeded the need since the backup "peasant labors" are such a large group. The nature of "the peasant labor" possessing the land and other means of production and the separated household registration system of urban and rural areas determine that they are short-term "peasant labors" instead of the longterm "employees." Most of them headed back home at the end of every year and might not come back to the same enterprise again. Since the number of "peasant labors" is an oversupply in total, the short-term peasant labor effect does not greatly affect the employment of enterprises. The "labor-intensive" industries need low-caliber labors who are prone to be replaced, which means that when a group of "peasant labors" take off, there will be several supplements. Apart from that, oversupply means enterprises can purchase laborers at an extremely low price and this low-cost pattern sustains the development of "labor-intensive" and low added-value industries. This is the so-called secret of "demographic dividend."

However, this development pattern of low added-value industries is unsustainable. From the aspect of the countryside, since young adults are attracted to cities, many places are turning into "empty nest," which leads to a great waste of land. The situation makes it impossible to meet the need of food, which means the food supply will be controlled by others because of the large quantity of food import. From the perspective of national strategy, longterm lower-end industries lead to the cost of high energy consumption and high pollution, while receiving low income, low added value and low domestic demand in return; this pattern could result in the severe polarization and excess production capacity, which will further lead to the consequence of being easily affected by the international financial crisis, finally bringing about the macroeconomy and society problem. The situation decides that Chinese economy has entered into "new normal." From the point of "workforce," owing to the economic development of the whole country, the increasing living cost of laborers leads to the improvement of the value of labor power, which indicates enterprises will face the pressure of rising wages. Rise in wage cost makes enterprises lose their competitive edge and even unable to maintain production because of the low profit of the lower-end industries. Apart from that, the labor productivity in rural areas increases at the same time, which means the gap between the income of "being a farmer" (including rural industry and commerce) and "being a worker in the city" has been narrowed. With the means of production back home, the peasant laborer could go back to be a farmer or start a business. This is why enterprises always face the dilemma of "labor shortage" after the Spring Festival in previous years. That is to say, the continuation of this developing pattern will put both rural and urban economies into a dangerous position.

To alter the situation, China's industrial system must be upgraded. However, the upgrades cannot be realized rapidly through the spontaneous action under the market mechanism, which needs national strategic layout, the establishment of the national innovation system and institutional arrangement that suits the situation better. The government has a clear understanding of the situation of our economy, which has entered "new normal." The government has formulated strategic policy of "new era" on industrial upgrading and makes decision to "revitalize the rural economy." 
4.2 Adhere to the collective ownership of land on the direction of rural reform

According to "answer from Marxist Economics to Weber's hypothesis about China," if China plans to carry out a capitalist mode of production, the condition of turning workforce completely into commodity needs to be created, which deprives the land from farmers and forces them to become freemen with "nothing at all." Depriving farmers' land can be realized by violence or the way of land privatization that leads to land annexation naturally. Then, most farmers will lose land once again, becoming freeman with nothing. Deprivation by "violence" in China is only a kind of theoretical hypothesis and has no feasibility; however, there is a possibility of "the theory of land privatization." Researchers and practitioners all stand for the land privatization in China or privatization in a different way. The proposal represents the willingness and interest of capital, meanwhile, it meets the law of the capital operation in "answer from Marxist Economics to Weber's hypothesis about China." If the proposal was realized, will the development be kept in line with the idea of the supporter of land privatization?

After thinking about the situation after the founding of new China, the answer can be easily found. Because of the incomplete capitalist mode of production in China, the bourgeoisie was pretty weak and incapable of finishing the mission of bourgeois-democratic revolution. The mission was finally accomplished by the "workers and peasants revolution" led by the Chinese Communists, which divided the revolution into two parts: "new democratic revolution" and "socialist revolution." The establishment of new China marks the victory of the "new democratic revolution" that enables farmers across the country to become commodity producers with private land through the policy of "land reform." If China's revolution had stayed at this stage, it would have happened to be the situation of "land privatization" assumed earlier. Under the circumstance of land privatization, if the trade of land was allowed, the land would be most likely to be centralized into the hand of minorities by the function of the law of value, which might cause the redistribution of the landlord and peasant class, returning back to the state of semifeudal and semicapital capitalism before liberation when rural labors have trouble transforming into a commodity. If the land transfer was forbidden by law, rural areas would stay at the state of "small-scale peasant economy" eternally where land cannot be managed in large scale and the productivity of rural labor cannot be promoted, which means there is no surplus products and labors for the capital accumulation of "industrialization," let alone the "labor commodity." No matter what kind of social system is implemented, industrialization and urbanization are the only way to modernization. From that, under the condition of land privatization, whatever the way is chosen, the way of capitalist (or the way of new democracy) or the socialist way (there will be no socialism after the privatization of rural land!) was to carry out, the task of industrialization and urbanization cannot be accomplished.

After the reform and opening-up, under the premise of adhering to the collective ownership of land, the government has implemented the "contract management responsibility system" in the rural areas, which was quite necessary at that time. After several decades' construction on the market economy, the defects of the "small-scale peasant economy" have been increasingly obvious. Therefore, the Party Central Committee proposed a new "four modernizations": industrialization, urbanization, informatization and agricultural modernization, and put forward the slogan of "revitalizing the rural economy." Urgent issues before us are how to revitalize the rural economy and determine the direction of rural reform. Revitalizing the rural economy is to alter the dispersed operating procedure of the rural areas and raise the productivity of rural laborers. Besides, at the premise of guaranteeing the food self-sufficiency of China, more surplus laborers should be freed to provide labor power for industry and commerce. China should realize its industrialization, urbanization and informatization as soon as possible, building its modern economic system as well as improving its socialist system with Chinese

\section{Direction of rural reform in China}


CPE 3,1

characteristics. In conclusion, under the condition of land privatization, the task of realizing industrialization and urbanization cannot be accomplished. So, the direction of Chinese rural reform can only be the socialist way with Chinese characteristics. The task of revitalizing the rural areas can only succeed at the premise of adhering to the collective ownership of rural land, meanwhile, reforming and improving the operating procedure.

\subsection{The fundamental way is the "integration of agriculture, industry and commerce" of the rural economy}

Now that the land privatization cannot provide "labor as a commodity" for urban industries and commerce in essence, why can the way of adhering to the collective ownership of rural land provide "labor as a commodity" for urban industries and commerce? This leads to two questions: (1) How to solve the labor problem of the development of urban industrial and commercial economy? (2) How to deal with the rural surplus labors?

To the first question, the urban economy consists of two parts: one is the state-owned economy that is owned by the whole people, and the other is the private economy including foreign investment. According to the analysis, if there was no state-owned economy left, which means private ownership would conquer all, capitalist enterprises could not be able to purchase enough "labor as a commodity" to develop their production. Without the supply of long-term "labor as a commodity," the quality of laborers would stay at a low level and the upgradation of the industry would approach a bottleneck. Because of this, we should also adhere to the publicly owned economy as the main body in the urban economy, in which the labor should be differentiated from that in the private economy in the nature of goods. The labor of the rest of the private sector belongs to commodity. The "employment issue" of this kind of enterprise can be dealt with by employing existing urban new employment populations (including graduates from rural areas who mostly graduated from middle schools or universities), which solves the contradiction of "the peasant laborer" problem.

The second is the issue of rural surplus labors. A part of the rural surplus laborers can be employed by the state-owned economy. For the rest, the only feasible solution is the industrialization and urbanization of local areas. The way of realizing rural industrialization and commercialization should be in line with local conditions and can be diverse: (1) The Nanjie Village Scheme: the land and other means of production are collectively owned and operated, and an agricultural-industrial-commercial complex is established. (2) The Cooperative Shares System: farmers can use contracted land and other means of production as shares to implement the joint-stock system, carry out a large-scale operation and build a joint venture of agriculture, industry and commerce. (3) The land transfer: farmers transfer the contracted land to enterprises with the business capacity to carry out the joint operation of agriculture, industry and commerce and participate in the dividend. And the labor power of farmers is sold to the enterprises and they become the employees of the enterprises. Industrialization and townization of local rural areas, rather than "urbanization" of all rural areas, are an important part of the modern economic system with Chinese characteristics.

\section{References}

Feng, T. (1990), "Three problems in the study of pre-capitalist society in China", Tianjin Social Sciences, Vol. 10 No. 4, pp. 75-81.

Guo, M. (2015), "Religious ethics promotes the rise of Science - 'Merton proposition' under the influence of 'Weber proposition' and its practical significance”, Southeast Academic Research, Vol. 37 No. 3, pp. 83-89. 
Liu, Z. and Zhang, Y. (2013), "Can Chinese feudal society give birth to the capitalist system independently: a re-examination to the clasic proposition", China Review of Political Economy, Vol. 12 No. 4, pp. 211-223.

Liu, M. (1995), "On the economic structure and modernization transformation of the feudal society in China and the West", Journal of Jinan University, Vol. 59 No. 1, pp. 11-16.
Direction of rural reform in China

Tang, W. (2005), "China's business revolution and the budding of capitalism in the 16th-18th century", Study of Chinese History, Vol. 27 No. 3, pp. 143-156.

Wang, Y. (2000), The Original Theory about China's Economy, Guangdong Economy Publishing House, Guangzhou.

Xia, Z. and Zhan, J. (2002), "A new view on the reasons for the sluggish modernization of Chinese capitalism”, Academic Journal of Zhongzhou, Vol. 23 No. 1, pp. 121-123.

$\mathrm{Yu}$, C. (1991), "Chinese inventions promoted the emergence of European capitalism", Academic Monthly, Vol. 35 No. 5, pp. 22-23.

Zhang, Z. and Ma, Z. (1987), "Marx's discussion on the reason why the feudal society of Asian countries stagnated for a long time", Theoretical Investigation, Vol. 4 No. 1, pp. 84-88.

Zhou, G. (2010), 'From the perspective of the basic social structure, 'the sprout of Chinese capitalism' is a false proposition - a discussion with Mr", Yang Shiqun and Mr. Cao Shouliang, Zhejiang Social Sciences, Vol. 25 No. 10, pp. 58-63.

Zhu, H. (2001), "On the conditions of Chinese capitalism”, The Journal of Shanghai Administration Institute, Vol. 2 No. 1, pp. 43-54.

\section{Corresponding author}

Jiguo Yang can be contacted at: xmyjg4486@189.cn

For instructions on how to order reprints of this article, please visit our website:

www.emeraldgrouppublishing.com/licensing/reprints.htm

Or contact us for further details: permissions@emeraldinsight.com 